\title{
Improvement in the structure of Russian tax authorities: present status
}

\author{
Timergaziz Sadykov* \\ Ufa State Petroleum Technological University, Branch of the University in the City of Oktyabrsky, 54a, Devonskaya St., Oktyabrsky, \\ Republic of Bashkortostan, 452607, Russia
}

\begin{abstract}
The tax system existing in Russia needs further improvement. In the near future, its enhancement should be aimed at using tools of the tax system in order to increase the welfare of people and ensure stable growth of the national economy. This article highlights features of the tax system, the structure of tax authorities at the present stage. The author reveals peculiarities of their functioning and shortcomings, analyzes changes taking place.

Keywords: taxes, tax system, budget, economy, taxation, inspection, structure, region, personnel, reform.
\end{abstract}

\section{Introduction}

The most important task of the country now is to turn its economy into a competitive one, actively participating in global economic relations.

The tax system is considered the most active lever of state regulation of socio-economic development, investment strategy, external economic activity, structural changes in production, accelerated development of priority sectors. [11]

Over the past decade, the Russian tax system has been constantly experiencing changes, and legislative bodies of the Russian government, including those in the regions, are constantly searching for optimal solutions in the field of taxation and its structure. The need to improve the structure of tax authorities is long overdue: it became clear that the existing structure does not fully meet the requirements of today.

\section{Regeneration of tax system in Russia}

The history of domestic tax system is associated with formation of the old Russian state. The first mention of tribute collection dates to the reign of Prince Oleg (912). The chronicle "Tale of bygone years" enumerated peoples "who pay a tribute to Rus".

Tribute (duty) was one of the main taxes, including direct tax and pay quitrent, which were paid in kind: fur, even swords, and, basically, specifying the period of wars and campaigns.

In the era of the Golden Horde (1243-1483) to introduce a centralized tax system, representatives of the Horde authorities conducted a census of the population of Russia ("number" or "count"), on the basis of which Mongolian baskaks (authorized officials) collected a tribute.

In the 15 th century, the cessation of tribute payment to the Golden Horde began the creation of a financial system of Russia. During the time of Ivan the Terrible
(1530-1584), the first Russian Tsar, many taxes and fees were levied in the form of money.

In 1646, the government of Alexei Mikhailovich (1645-1676) introduced high duty on salt, which was to replace the strelets (or Marksman Troops) money as well as yam duty (levied onto both urban and rural populations). However, salt became twice as expensive as it was previously, so people bought so little of it that the Treasury did not benefit from the new tax, and it was canceled in 1647.

From 1679 to 1681 Prikaz ("office") of Grand Treasury was put in charge of financial institutions of the Muscovite state, and then the Burmister Chamber (later Ratusha or Town Hall) was distinguished out of it. It was entrusted with overall control of the Zemstvo izba (an elected body of local self-government), assessment and collection of taxes.

During the reign of Peter I, the tax system was complex and included such taxes as: tax on beards, axes, and even oak coffins. Significant changes in the tax system occurred with the change in the administrativeterritorial division of Russia and creation of the post of Governor, responsible for monitoring taxes collection in those years.

In 1725, a Table of state income and expenditure was compiled. Financial reforms allowed the state to increase revenues more than threefold in 15 years. (In $1710-$ 3.1 million rubles, in $1725-10.2$ million rubles), at the same time there was regularly a surplus of income over expenditure.

The rule of Anna Ivanovna (1693-1740) involved several decrees on dealing with arrears.

Elizaveta (Elizabeth) Petrovna, Empress of All Russia (1709-1762) established permanent excise duties on wine and vodka and introduced special labels for the transportation of alcoholic beverages.

In the reign of Catherine II (1762-1796), the main tax was a per capita tribute, which accounted for up to $33 \%$

\footnotetext{
* Corresponding author: riuof@mail.ru
} 
of state revenues. The Empress managed to simplify the tax system.

Paul I (1754-1801) continued to replace partially the natural duties with monetary fees; the position of the state Treasurer was established, the activity of Peter the Great's Collegia in the field of financial management was restored.

In the years of the reign of Alexander I (1771-1825), they reformed a number of taxes, quitrent, guild fee, etc., established a percentage levy on income from immovable property. The Manifesto of 1802 "On the establishment of ministries" founded the Ministry of Finance and defined its role, and appointed Count A.I. Vasilyev as the first Minister of Finance

Under Alexander III (1845-1894), changes in the tax system continued: they canceled per capita tax, increased excise on alcohol, introduced excise on matches and taxes on inheritance and monetary capital. The year 1893 was marked by the issue of "the Highest Manifesto of forgiveness of wages arrears".

During the reign of Nicholas II (1868-1918), the last Russian Tsar, such public figures as S.Yu. Vitte and P.A. Stolypin initiated several reforms. In 1895-1897, there was a monetary reform that set the gold standard. They increased the structure of tax inspection, reformed the excise supervision system due to establishment of a wine monopoly. P.A. Stolypin developed a project to transform and change public administration and tax system in Russia, which can be considered as the most radical program to reform the tax sphere in the first half of the 20th century in the world.

Those actions resulted in a well-established system of financial revenues. On the eve of the First World War, Russia occupied a strong financial position.

In the first years of the Soviet regime they nearly eliminated the tax system. In 1918, the decree of the Council of People's Commissars abolished the financial bodies in Russia, and it transferred the collection of taxes to the jurisdiction of established financial departments of Provincial and Uezd Executive committees.

The direct expropriation of the bourgeoisie was of first importance, not tax revenues.

The first tax decrees of the Soviet regime were: of November 27, 1917. - "On collection of direct taxes, on payment of the income tax on salaries; penalties and administrative sanctions for violation of terms of taxes introduction (up to confiscation of property and imprisonment) and adjudgment to execution of regulations of the Decree by forces of the Red guard and militia".

In 1921 the People's Committee of Finance established the Office of Tax and Government Revenue as its part and abolished the position of assessors in the Uezd financial departments.

During the period of new economic policy (NEP) (1921-1930) there was a restoration and development of the tax system. Indirect taxes became very important. Excise duties on several goods were introduced: salt, sugar, kerosene, tobacco products, matches, textiles, tea, coffee, vodka. In total, 86 types of payments to the budget were in effect during the NEP.
The tax reform of the early 1930s complicated the tax system that resulted in a plurality of tax rates. Among the taxes levied on citizens, tax on personal income was the most important.

The excise system was completely abolished, in the late 1930s they created tax districts, the position of tax agents was introduced in the villages.

During the Great Patriotic War (1941-1945), due to the need to mobilize resources, the authorities established a $100 \%$ rate of income and agricultural tax, which was then replaced by a military tax, abolished after the war. In addition, they imposed a tax on bachelors, single and small-family citizens.

Another reform of the Russian tax system was introduced in the 1960s. Tax inspections were combined with state revenue inspections, a mandatory payment of state enterprises called "payment for fixed assets and working capital" was established, and income tax from collective farms was introduced.

In the 1970s, they reduced taxes on the population, abolished taxes on wages of workers and employees receiving up to 70.0 rubles per month. [5]

In the 1980s, there were local taxes: on the owners of buildings, land tax, tax on vehicle owners.

The 1990s were the years of full-scale enhancement of the tax system in Russia.

In 1990, the State Tax Service was created as part of the Ministry of Finance of the USSR; on November 21, 1991 Decree of the President of the Russian Federation No. 229 established the State Tax Service of the RSFSR - an independent Executive body of the Federal level. There were appointed regional state tax inspectorates and subordinate state tax inspections for cities and districts. The Law of the Russian Federation "On the formation of tax system of the Russian Federation" was passed.

In 1998, the State Tax Service of Russia was transformed into the Ministry of taxes and duties of the Russian Federation. The Tax code adopted in the same year made it possible to systematize, rearrange and bring into a single system the existing rules and regulations governing the taxation process.

Decree of the President of the Russian Federation of March 9, 2004. No. 314 "On the system and structure of Federal Executive bodies" transformed the Ministry of taxes and duties of the Russian Federation into the Federal Tax Service.

\section{Tax system at the present stage}

Tax system is a single set of homogeneous elements that perform a single task - the removal of taxes and fees from the subjects of tax into relevant funds of territorial entities.

Tax system of any state can be considered as a legislatively adopted in the state set of taxes and fees, withdrawn by the relevant authorities from the subject of tax (taxpayers). [2]

Requirements for the tax system at the present stage can be considered as follows:

- rationality; 
- optimality;

- easy calculation of taxes;

- accessibility and transparency for taxpayers;

- equity;

- economic feasibility;

- efficiency, etc.

Analysis of tax systems of many countries shows that, despite their differences, they have in their composition (structure) similar elements, although in different combinations.

Two conditions are necessary for the tax system to function effectively in contexts of market relations and to stimulate the producer and the employee's labor, they are:

- to reduce the tax burden by decreasing the number of taxes and their rates;

- to make the tax system clear, transparent, simple, accessible to the subject of tax, economical and easy to calculate taxes with optimal-minimum staff of tax officials. [3]

The analysis of the tax system of Russia and foreign countries conducted by economists reveals several areas for improvement in the tax system and resolution of problems in the tax sphere, the main of which are:

- creation of an economical and efficient tax system with a simplified tax base;

- creation of a tax system considering specific conditions and foreign policy as well as internal changes in the situation.

\section{Structure of the tax service}

Legislatively, the entire tax system can be controlled by the Tax Code of the Russian Federation - this is the main legislative document, which prescribes all the rules and duties of the tax authorities. The Tax Code consists of two parts. In addition to the Code, there are several legislative acts and laws aimed at monitoring and ensuring order in the field of the tax system. [9]

The modern tax system has a three-level structure:

The first level is the Federal Tax Service;

The second level is the Interregional Tax Office;

The third level is the FTS of Russia.

The first (lowest) level is the Federal Tax Service. These units are located on the territory of cities and other settlements, exercising control over the collection, calculation, processing of taxes and fees within the territory under their jurisdiction.

The second level is the Interregional Tax Office; it works on the territory of the largest regions of our country and is subordinate to all Federal tax services which are part of the region.

The third level is the FTS of Russia. It is responsible for monitoring all interregional tax services, as well as for resolving all the most important issues related to tax revenues, deduction and calculation. Besides, main duties of the Federal Tax Service involve developing new projects on the tax system.

The Federal Tax Service plays a leading role and is important in accumulating all tax processes within the current legislation. The head officer of the Tax system is appointed and released exclusively by the Government on the proposal of the Minister of Finance of the Russian Federation.

Tax authorities form a single centralized system with a vertical structure of subordination and appointment.

General structure of tax authorities includes link units operating at interregional and inter-district levels (figure 1). [9]

The structure of tax authorities is approved by the order of the Federal Tax Service of Russia. Each tax authority is a legal entity, but at the same time is in a vertical subordination and is a part of a single centralized system.

\begin{tabular}{|c|c|}
\hline \multicolumn{2}{|c|}{ Ministry of Finance (MinFin) of Russia } \\
\hline \multicolumn{2}{|c|}{ Federal Tax Service (FTS) of Russia } \\
\hline \multicolumn{2}{|c|}{$\begin{array}{c}\text { Department of FTS of Russia on subjects of the } \\
\text { Russian Federation }\end{array}$} \\
\hline $\begin{array}{l}\text { Organizations under } \\
\text { supervision of } \\
\text { FTS of Russia }\end{array}$ & $\begin{array}{c}\text { Interregional and } \\
\text { territorial inspections of } \\
\text { Russia }\end{array}$ \\
\hline
\end{tabular}

Fig. 1. Diagram of structure of tax authorities

Main objectives of the existing tax structure are:

- total and timely control over all legislative obligations;

- correctness of calculation and assessment of tax burden;

- control over timely payment of tax liabilities of taxpayers in every city, region, country;

- implementation of currency control throughout the country in accordance with the law.

Between the Federal Tax Service (FTS) and its territorial offices there are interregional inspections of the Federal districts.

At the interregional level, there are inspections for the largest taxpayers in the areas of: [6]

1. Exploration, production, processing, transportation and sales:

- oil and refining

- natural gas.

2. Production and turnover of ethyl alcohol from all types of raw materials of alcoholic, alcohol-containing and tobacco products.

3. Electrical power industry - production, transmission, distribution of electricity and heat.

4. Production and sale of metallurgical industry products.

5. Transport services.

6.Provision of communication services.

At the level of subjects of the Federation, there are departments (of republics, territories).

Head of the Federal Tax Service in coordination with the Plenipotentiary representative of the President of the Russian Federation for the relevant subject appoints heads of the Federal Tax Service department. 
At the local level, there are inspections for taxes and levies on regions, districts in cities and towns without district division. In general, it coincides with the level of local self-government except for such situations as Moscow and St. Petersburg, where the organization of local self-government is different.

The chief inspectors are appointed by Head of FTS of Russia upon the recommendation and in coordination with Head of the office of constituent entities of the FTS.

Territorial inspections of the Federal Tax Service are the main structural element of tax authorities of the Russian Federation. They are created in one municipality (district, city) or several municipalities. [5]

\section{Improvement in the structure of tax authorities of the Russian Federation}

Improving the structure of tax authorities of the Russian Federation takes place in context of implementation of the administrative reform.

The problem of improving the tax system is multifaceted, includes many aspects and among them, the management of tax processes, hence, the management of the structure of tax authorities.

In organizational terms, the system of tax authorities is responsible for control and supervision in the field of taxes and fees by the Federal Executive body and its territorial bodies.

Consequently, issues related to modernization and changes in the structure of tax authorities are relevant for the Executive branch.

Since 1991, the name of tax authorities has changed several times. At different stages this function was performed by: [7]

- from 1991 to 1998 , the State Tax Service of the Russian Federation (STS of Russia);

- from 1994 to 2004, the Ministry of Taxes and Duties of the Russian Federation (MTD of Russia);

- from 2004 to the present time, the Federal Tax Service (FTS of Russia). [10]

\section{Main directions for improvement in the structure at the present time}

The problem of improving the efficiency of tax authorities is very acute at the present stage. It should be noted that organization of territorial, local tax authorities is far from perfect: low level of tax collection, debt growth, low rate of additional charges according to the territorial entities, the cities, lack of opportunities for organizations and individual entrepreneurs to produce self-assessment of their payments to the budget, nontransparency, lack of relevant information.

Economists suggest that one of the main tasks of improving the organizational activities of territorial tax authorities is the transition from the dominant structure of inspections with a strongly marked specialization of departments by types of taxes to the predominantly functionally oriented inspection structures. [4]
The point is to ensure rational use of the personnel of inspections according to specialization in the functions performed.

Optimization of the structure of district, city tax inspections carried out in 2008-2013, by reducing the number and consolidation of tax inspections, had no expected results.

The results of analytical work show that only in the Republic of Bashkortostan 14 of 26 existing inspections are currently operating. The reduction was $35 \%$. In the whole country, 17,390 employees of tax authorities had been reduced in number by January 2013. [1]

Such large industrial cities of the Republic as Oktyabrsky, Belebey, Salavat, Kumertau, as well as medium-sized cities: Dyurtyuli, Meleuz, Mezhgorie, Agidel, Baymak are left without tax authorities, which are necessary for the population of urban districts, enterprises and entrepreneurship. [6]

As a result of changes in the structure of tax authorities, we have a reduction in additional charges, collection, increase in debt and consequent dissatisfaction of taxpayers.

During the years of tax reform there have been some positive changes, both in the structure of tax authorities and in the structure of tax revenues for the main sectors of economy. While maintaining a high share of industry, the share of taxes paid by fuel industry (primarily related to oil production and processing) has increased significantly. [8]

Legislative registration of the structure of tax system in Russia is considered one of the latest measures.

\section{Conclusion}

The structure of the Russian tax system developed in 1991 is subject to constant changes. Today there is a huge, theoretically generalized and meaningful experience of collection and use of taxes in many countries of the world.

Over a long period of time, mistakes were made in reforming the state's tax strategy.

The analysis of papers written by many economists shows that the abundance of guidelines is the problem of incompleteness and inconsistency of the legislation, when some say one thing, others - quite the opposite in meaning. [11]

There is the contradiction between legislative acts and methodological instructions annexed to them. Significant financial resources are regularly spent on meaningless reorganizations within the tax system, when one tax inspection structure is approved today, then tomorrow it is completely different, which leads to a huge waste of money and human resources.

Clarification and generalization of tax functions, improvement of the structure of tax authorities, an integrated approach to taxpayers will further allow turning to a more flexible system of tax authorities' response to their tasks. 


\section{References}

1. About optimization of number of Federal public servants and employees of Federal public authorities; the Decree of the President of the Russian Federation of 31.12.2010 no. 1657

2. L. Forni M. Pisani, Macroeconomic dynamics, 22(2), 470-500 (2018). DO1: 3651100516000286I:10.1017/S

3. M.A. Mateo-Perez, M.A. Martinez-Roman, Domenech-Lopez, Revista de cercetaresiinterventie sociala, 50, 96-110 (2015)

4. E.R. Toro, Revistagestion de las personas y technologia, 9(25), 6-19 (2016)

5. M.V. Goryunova, L.S. Kuleshova, A.I. Khakimova, Application of signal analysis for diagnostics," IEEE (Int. Conf. on Industrial Engineering, Applications and Manufacturing (ICIEAM)), pp. 1-5 (2017). DOI: 10.1109/ICIEAM.2017.8076487

6. T.G. Sadykov, R.R. Stepanova, Municipal budgets under conditions of economic crises in Russia. SHS Web of Conf. (CILDIAN-2018 - Current Issues of Linguistics and Didactics: The Interdisciplinary Approach in Humanities and Social Sci.), 50, pp. 1-3 (2018). Number of the article 1219. DOI: 10.1051/shsconf/ 20185001219economics

7. Sadykov T.G. Formation of expenses of the budget Financial Economics, 4, 22 (2009)

8. N.T. Dao, O. Edenhofer, J. of macroeconomics, 55, 253, 273 (2018)

9. M.V. Mishustin, Improvement of tax administration tools to ensure stable revenues of the state budget, Economy. Taxes. Law, 4(8) (2014)

10. Federal tax service of Russia, Retrieved from: http:/www.nalog.ru/ru

11. V.G. Shelepov, A.K. Isaev, Improving the structure of tax authorities. Problems of innovation, investment and financial activities (Rostov-on-Don: URGUES, 2013) 